\title{
A test of half-sib progenies of greyish oak, Quercus pedunculiflora K Koch
}

\author{
V Enescu \\ Forest Research and Management Institute, Bucharest, SOS Stefanesti 128, 72904 Romania
}

\begin{abstract}
Summary - Results of an open pollinated progeny test of Quercus pedunculiflora are presented. The experimental design was Youden square with 9 replicates. The material comprised 23 openpollinated progenies coming from a clonal seed orchard and 2 controls: 1) bulk collection from a superior population and 2) bulk collection of an average stand. After 14 years, important differences between controls and tested families were observed. All families except 1 showed superiority for stem straightness to the controls. The data supported the effectiveness of selection for stem straightness.
\end{abstract}

\section{Quercus pedunculiflora / open-pollinated progeny / clonal seed orchard / plus tree}

Résumé - Un test de descendances de Quercus pedunculiflora K Koch. Cet article rend compte d'un test de descendances issues de pollinisation libre de Quercus pedunculiflora. Le dispositif expérimental était constitué de carrés de Youden avec 9 répétitions. Le matériel végétal comprenait 23 descendances issues d'un verger à graines de clones et de 2 lots témoins: 1) un lot de graines récolté en vrac dans un peuplement phénotypiquement supérieur et 2) un lot récolté en vrac dans un peuplement moyen. Après 14 ans, des différences importantes ont été observées entre les descendances et les lots témoins. Toutes les familles à l'exception d'une montrent une meilleure rectitude du tronc que les témoins. Les données montrent l'efficacité de la sélection d'arbres plus pour la rectitude du tronc.

Quercus pedunculiflora / descendance issue de pollinisation libre / verger à graines de clones / arbre plus

\section{INTRODUCTION}

In Romania, many species of Quercus with very strong polymorphism grow naturally. They are identified as various subspecies, varieties, interspecific hybrids and introgressants (Savulescu, 1952). Of the 6 native species of Quercus, greyish oak ( $Q$ pedunculiflora) is localized in the south and east of the country (in Oltenia, Muntenia, Dobrogea and Moldova). It is a forest-steppe species, more thermophilous and more xerophytic than Quercus robur. Greyish oak is absent from the flora of Banat and Transylvania. It forms pure stands over small areas, in the outlying forest-steppes, on leached chernozem or in uplands and on dunes. 
Greyish oak is the most important species of the Romanian forest--steppe. For this reason, since 1958, many biosystematical studies have been conducted on natural populations. Plus trees have been selected, and, between 1961 and 1962, seed orchards of greyish oak have been established (Enescu and Enescu, 1963). The 2.5-ha seed orchard was placed in Oltenia, near the town Craiova, in the Jiu river valley, at $100 \mathrm{~m}$ of altitude, just on the outer limit of the forest zone.

The seed orchard comprises 29 clones; ramets are completely randomized, with the restriction that ramets of a clone are separated by at least 2 ramets of another clone.

In the second year after establishment, many plants began to blossom and yield viable acorns (Enescu and Enescu, 1966 a,b; Enescu et al, 1975). Observations in 1969 showed that all clones blossomed and, from the total number of ramets forming the seed orchard (initial planting scheme was $4 \times 4 \mathrm{~m}$ ), $73.9 \%$ yielded sound acorns. Under these conditions, it was decided to test half-sib progenies. First, a nursery test was carried out, then a set of 3 comparative cultures was set up in Cernica, Peisor, and Vinjul Mare, aimed at assessing plus trees and their crosses in seed orchards under conditions of relatively full isolation against foreign pollen, in comparison with bulked descendants of a normal natural population and a plus population, classified according to Lindquist (1954).

\section{MATERIALS AND METHODS}

From the 1969 crop of the Craiova seed orchard of greyish oak, acorns from 27 clones were harvested keeping each clone separate.

In the summer of 1970, at the Forest Experimental Station Craiova, a nursery test was carried out for 2 years. As the control, freely pollinated acorns from an average population at Perisor-Dolj were used. A simple lattice with 4 replicates was used as the experimental design.

In spring 1971, in the south of the country (Oltenia and Muntenia), 3 comparative tests were established at Cernica (near Bucharest), Perisor (near Craiova) and Vinjul Mare (near Turnu-Severin) within a zone characteristic for greyish oak. The so-called Youden square (Youden, 1940) with 9 replicates was used as the experimental design, testing 23 families and 2 controls; bulked descendants of population Praporul-Caracal (PC) were classified as superior (the best natural population of greyish oak known in Romania; at present deforested) and those of population Lilieci Branesti (LB) were classified as average. Each plot was comprised of 9 plants.

ANOVA was used to test for family differences. Student's $t$-test was used to compare family mean values.

\section{RESULTS AND DISCUSSION}

Results of the nursery test and those from the experimental plantations CernicaBranesti are briefly presented but conclusions are based on all data obtained over a period of several years.

The nursery test revealed significant differences between the tested families and the control, as regards total height, number of branches grown in the first vegetative season, and number of shoots during a vegetation season (polycyclism). When compared to the control represented by a bulk collection in an average natural stand, som of the half-sib families showed inferior growth. For example, families 8, 12, 16 and 27 were inferior to the control in height. For the number of shoots produced during a vegetaton season, only families 16 and 26 were significantly superior to the control.

Height increments were measured in 1972. Variation ranges from 47.4 (family 
12) to $32.1 \mathrm{~cm}$ (family 26 ). At the $5 \%$ probability level, important differences were found between averages of some openpollinated families and the tested controls (table 1 and fig 1). The control superior population (PC) was located in the middle of the ranking, in the same class of variation as the average control population (LB). The continuous variation suggests polygenic control of growth.

After 11 years, in 1983, at the age of 14 (2 $\mathrm{yr}$ in nurseries and $12 \mathrm{yr}$ outplanted) more characteristics were measured. Total height showed a relative narrow continuous range of variation (fig 2). Important differences occurred between openpollinated families and the controls (table 1). Breast height diameter of the stem

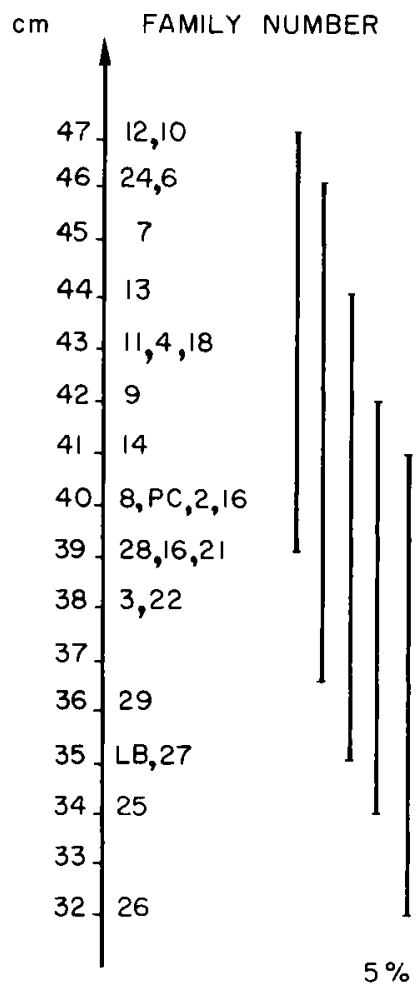

Fig 1. Ranking of family mean values for height increments in $1972(\mathrm{~cm})$. showed a similar pattern of variation (table 1). The range of variation was narrower, varying between 10.03 (family. 25) and $11.93 \mathrm{~cm}$ (family 15). Controls LB (10.10 $\mathrm{cm})$ and PC $(10.20 \mathrm{~cm})$ showed intermediate positions between these extremes.

The effectiveness of plus tree selection in spite of the obvious superiority of many half-sib progenies should not be expressed in too definite terms. Although selection of plus trees was carried out only in natural

\section{FAMILY NUMBER}
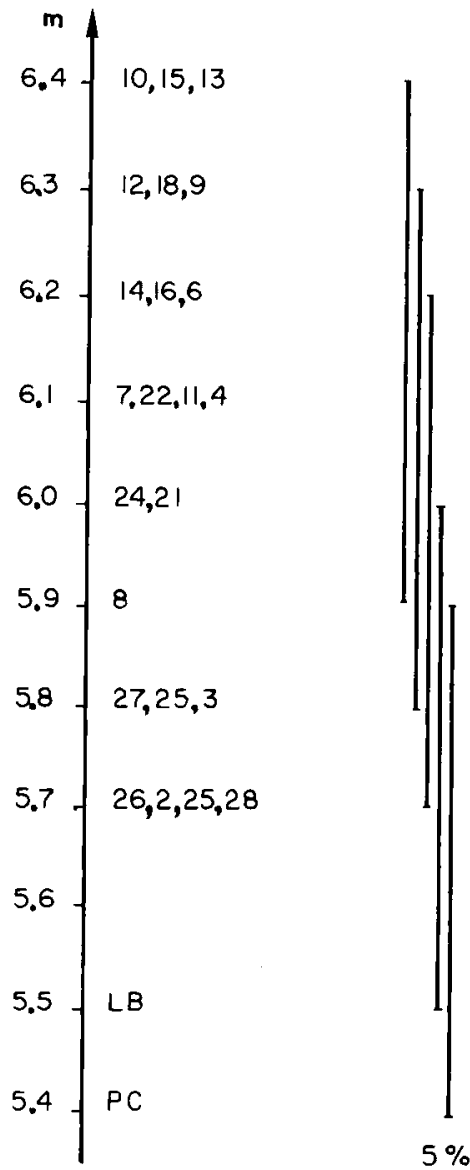

Fig 2. Ranking of family mean values for total height in $1983(\mathrm{~m})$. 
Table I. Results of analysis of variance for various traits.

\begin{tabular}{|c|c|c|c|c|}
\hline $\begin{array}{l}\text { Source of } \\
\text { variability }\end{array}$ & Sum of squares & $D F$ & Variance & $\begin{array}{l}\mathrm{F} \\
\text { calculateo }\end{array}$ \\
\hline \multicolumn{5}{|l|}{$\ln 1972$} \\
\hline Replications & 1487.000 & 8 & 185870 & - \\
\hline Blocks & 1034.000 & 24 & 43000 & - \\
\hline Entries & 3571.000 & 24 & 148000 & 1.91 \\
\hline Error & 11013.000 & 168 & 65000 & - \\
\hline \multicolumn{5}{|c|}{ Total height $(m)$ in 1983} \\
\hline Replications & 442.994 & 8 & 5174 & - \\
\hline Blocks & 0.085 & 24 & 0.004 & - \\
\hline Entries & 17.797 & 24 & 0.742 & 1.857 \\
\hline Error & 67.177 & 168 & 0.399 & - \\
\hline \multicolumn{5}{|c|}{ Breast high diameter $(\mathrm{cm})$ in 1983} \\
\hline Replications & 27.955 & 8 & 3494 & - \\
\hline Blocks & 1.456 & 24 & 0.061 & - \\
\hline Entries & 58.855 & 24 & 2.452 & 1.949 \\
\hline Error & 211.821 & 168 & 1.258 & - \\
\hline \multicolumn{5}{|c|}{ Stem straightness } \\
\hline Replications & 6.708 & 8 & 0.838 & - \\
\hline Blocks & 0.036 & 24 & 0.002 & - \\
\hline Entries & 8.586 & 24 & 0.358 & 3.694 \\
\hline Error & 16.272 & 168 & 0.097 & - \\
\hline
\end{tabular}

populations, these have been affected by the so-called "logging for diameter", removing only big trees. Consequently, a reverse selection was achieved, so that were selection has been carried out, the population failed to contain a wide variability of tree dimensions. This fact was known from biosystematical studies prior to the selection of plus trees. For this reason, attention was focused on selecting trees with the best stem straightness: rectilinear, cylindrical, well-pruned, unforked or forked in the upper third of the crown (fig 3).

In the experimental areas, shape of stem was evaluated by indices: 1) rectilin- ear stem; 2) with a slight curvature in one plane; 3) with curvatures over more planes.

The overall mean value of the scores in the test was 2.07 , standard deviation \pm 0.14 and the variation coefficient $-18.00 \%$. Significant differences existed between open-pollinated progenies and the controls.

At the $5 \%$ level of significance, there were important differences between controls PC and LB and all the tested families, excepting family 3 . Thus, offspring derived from a clonal seed orchard demonstrated superiority in comparison with material from plus and normal seed stand. At the 


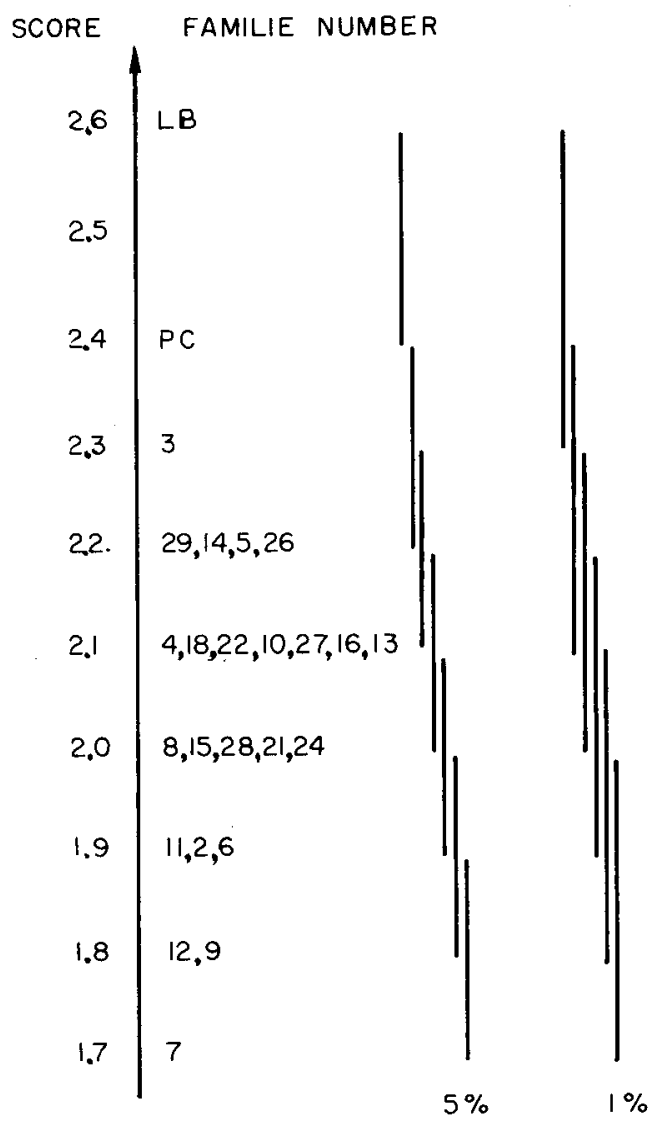

Fig 3. Ranking of family mean values for stem straightness scores (1983). same time, the effectiveness of selection of greyish oak trees for stem shape was demonstrated.

Heritability of stem shape, estimated according to Nanson (1970) was 0.701.

\section{REFERENCES}

Enescu V, Enescu V (1963) Alegerea arborilor plus de stejar brumario si stejar rosu. Rev Padurilor 2, 133-136

Enescu V, Enescu V (1966a) Inflorirea si fructificarea unui plantaj tînar de stejar brumariu. Rev Padurilor 11, 619-624

Enescu V, Enescu V (1966b) Floraison de quelques clones de Quercus pedunculiflora K Koch.Proceedings of IUFRO Meeting, section 22, Hungary, 147-155

Enescu V, Popescu GH, Enescu V, Badea N, Hulvtá C, Blada J, Cojocaru (1975) Inflorirea si fructificarea unor plantaje de pin silvestru, pin negru, larice, duglas si stejar brumariu. Rev Padurilor 3, 245-251

Lindquist H (1954) Forest Genetik in der swedischen Waldbaupraxis. Neuman Verlag, Berlin

Nanson A (1970) L'héritabilité et le grain d'origine génétique dans quelques types d'expériences. Silvae Genet 19, 113-121

Savulescu T (1952) Flora Romaniei. Academy of Romania, Bucharest, pp 656

Youden WJ (1940) Experimental designs to increase accuracy of greenhouse studies. Contr Boyce Thomson Inst 11, 219-228 